\title{
Development of a risk score for early saphenous vein graft failure: An individual patient data meta-analysis
}

\author{
Alexios S. Antonopoulos, MD, PhD, ${ }^{a}$ Ayodele Odutayo, $\mathrm{MD}, \mathrm{PhD},{ }^{\mathrm{b}}$ Evangelos K. Oikonomou, $\mathrm{MD}, \mathrm{PhD},{ }^{\mathrm{a}}$ \\ Marialena Trivella, BSc, MSc, DPhil, ${ }^{\mathrm{b}}$ Mario Petrou, PhD, FRCS (CTh), ${ }^{\mathrm{c}}$ Gary S. Collins, BSc, PhD, ${ }^{\mathrm{b}}$ and \\ Charalambos Antoniades, MD, PhD, ${ }^{a}$ the SAFINOUS-CABG (Saphenous Vein Graft Failure-An \\ Outcomes Study in Coronary Artery Bypass Grafting) group
}

\section{ABSTRACT}

Objectives: Early saphenous vein graft (SVG) occlusion is typically attributed to technical factors. We aimed at exploring clinical, anatomical, and operative factors associated with the risk of early SVG occlusion (within 12 months postsurgery).

Methods: Published literature in MEDLINE was searched for studies reporting the incidence of early SVG occlusion. Individual patient data (IPD) on early SVG occlusion were used from the SAFINOUS-CABG Consortium. A derivation ( $n=1492$ patients) and validation $(n=372$ patients) cohort were used for model training (with 10-fold cross-validation) and external validation respectively.

Results: In aggregate data meta-analysis (48 studies, 41,530 SVGs) the pooled estimate for early SVG occlusion was $11 \%$. The developed IPD model for early SVG occlusion, which included clinical, anatomical, and operative characteristics (age, sex, dyslipidemia, diabetes mellitus, smoking, serum creatinine, endoscopic vein harvesting, use of complex grafts, grafted target vessel, and number of SVGs), had good performance in the derivation (c-index $=0.744 ; 95 \%$ confidence interval [CI], 0.701-0.774) and validation cohort (c-index $=0.734 ; 95 \%$ CI, 0.659-0.809). Based on this model. we constructed a simplified 12-variable risk score system (SAFINOUS score) with good performance for early SVG occlusion (c-index $=0.700,95 \%$ CI, 0.684-0.716).

Conclusions: From a large international IPD collaboration, we developed a novel risk score to assess the individualized risk for early SVG occlusion. The SAFINOUS risk score could be used to identify patients that are more likely to benefit from aggressive treatment strategies. (J Thorac Cardiovasc Surg 2020;160:116-127)

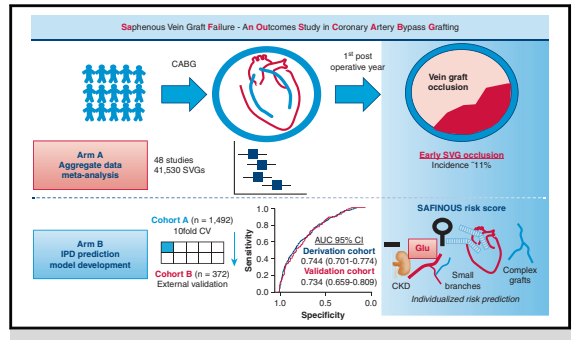

Summary of the study design and the main findings of each arm.

\section{Central Message}

A novel risk score (SAFINOUS score) estimates the individualized risk for early vein graft failure based on clinical, anatomical, and operative factors.

\section{Perspective}

The risk factors for early saphenous vein graft occlusion remain poorly understood as well as the optimal management of patients postoperatively. The developed SAFINOUS score could contribute to surgery planning or the guidance of treatment strategies postoperatively.

See Commentaries on pages 128 and 130.
From the a Division of Cardiovascular Medicine, Radcliffe Department of Medicine, and ${ }^{\mathrm{b} C e n t r e}$ for Statistics in Medicine, University of Oxford, Oxford; and ${ }^{\mathrm{c}}$ Department of Cardiac Surgery, John Radcliffe Hospital, Oxford University Hospitals NHS Trust, Oxford, United Kingdom

This study was funded by the British Heart Foundation (TG/16/3/32687, FS/16/16/ 32047 and PG/13/56/30383 to Dr Antoniades), the A.G. Leventis Foundation (scholarship to Dr Oikonomou), and the National Institute for Health Research (NIHR) Oxford Biomedical Research Centre (Drs Antoniades, Collins, and Channon). Dr Trivella is funded by a Cancer Research UK Programme Award Grant (grant number: C5529/A16895)

Ioannis Akoumianakis, Keith M. Channon, Laura Herdman, Marios Margaritis, Stefan Neubauer, Sheena Thomas (RDM Division of Cardiovascular Medicine, University of Oxford, United Kingdom), Stephen Fremes, Reena Karkhanis (Sunnybrook Health Sciences Centre, University of Toronto, Toronto Canada), Jeffrey Rade (University of Massachusetts, Worcester, Mass), Toshihiro Fukui, Hidefumi Nishida, Shuichiro Takanashi (Sakakibara Heart Institute, Tokyo, Japan), Ho Young Hwang, Ki-Bong Kim (Seoul National University Hospital, South Korea), Luigi Mannacio, Vito Mannacio (Universita Federico II, Naples Italy), Jota Nakano (Division of Cardiac Surgery, Bluhm Cardiovascular Institute of North- western University, Chicago, Ill), Louis Perrault (Montreal Heart Institute, Montreal Canada), Attila Kardos (Division of Cardiovascular Medicine, Milton Keynes University Hospital, NHS Foundation Trust, Milton Keynes, United Kingdom), Hitoshi Okabayashi (Tokyo Medical University Hospital, Tokyo, Japan), Dimitris Tousoulis (Department of Cardiology, Athens Medical School), Andrew Kelion, Nik Sabharwal (Department of Cardiology, Oxford University Hospitals NHS Trust, United Kingdom), George Krasopoulos, Rana Sayeed, David Taggart (Department of Cardiac Surgery, Oxford University Hospitals NHS Trust, United Kingdom).

Received for publication Jan 31, 2019; revisions received June 24, 2019; accepted for publication July 8, 2019; available ahead of print Aug 26, 2019.

Address for reprints: Charalambos Antoniades, MD, $\mathrm{PhD}$, Division of Cardiovascular Medicine, University of Oxford, John Radcliffe Hospital, Headley Way, OX3 9DU, Oxford, United Kingdom (E-mail: antoniad@well.ox.ac.uk). $0022-5223$

Copyright (C 2019 The Authors. Published by Elsevier Inc. on behalf of The American Association for Thoracic Surgery. This is an open access article under the CC BY license (http://creativecommons.org/licenses/by/4.0/). https://doi.org/10.1016/j.jtcvs.2019.07.086 


\begin{tabular}{ll} 
Abbreviations and Acronyms \\
\multicolumn{1}{c}{ CABG } & Coronary artery bypass \\
& grafting \\
CI & $=$ confidence interval \\
IPD & individual patient data \\
LIMA & $=$ eft internal mammary artery \\
MLMI & multilevel multiple \\
& imputation \\
SAFINOUS-CABG $=$ & Saphenous Vein Graft \\
& Failure-An Outcomes \\
& Study in Coronary Artery \\
& Bypass Grafting \\
SVG & $=$ saphenous vein graft
\end{tabular}

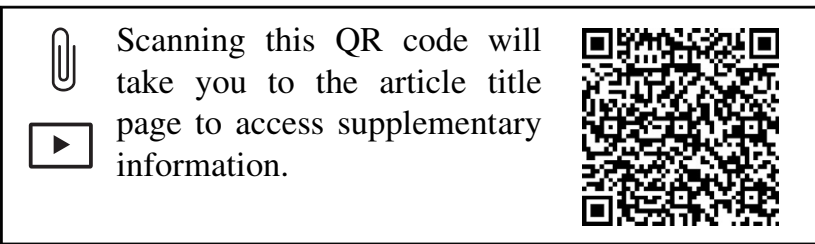

Coronary artery bypass grafting (CABG) surgery is a widely used revascularization strategy for complex multivessel coronary artery disease that improves prognosis and patients' quality of life. ${ }^{1}$ Although left internal mammary artery (LIMA) graft is the gold standard for left anterior descending revascularization, the saphenous vein is the most widely used conduit for $\mathrm{CABG}{ }^{2}$ However, saphenous vein grafts (SVGs) have a greater rate of both early and late occlusion compared with arterial grafts. ${ }^{3}$

Late SVG occlusion is attributed to atherosclerosis, whereas early SVG occlusion ( $<12$ months) is caused by thrombosis and/or intimal hyperplasia. ${ }^{2}$ Traditionally, early SVG occlusion is attributed to technical factors, but it could be affected by patient characteristics and/or operative factors as well. Although the long-term patency of SVGs has been extensively studied in several clinical studies, ${ }^{4}$ early SVG occlusion remains unclear. Surprisingly, there is a large discrepancy in the reported rates of SVG occlusion early post-CABG at 12 months. ${ }^{5}$ Previous reports suggest that female sex, ${ }^{6}$ diabetes mellitus, ${ }^{7}$ or off-pump surgery ${ }^{8}$ may affect graft patency; however, there is no comprehensive prediction model for early SVG occlusion.

A prediction model for early SVG occlusion could guide the deployment of effective prevention strategies. For example, dual antiplatelet treatment may improve early SVG patency, ${ }^{9}$ but the lack of cardiovascular mortality benefit ${ }^{10}$ and the risk of bleeding complications preclude its use in all patients with CABG. ${ }^{11}$ An individualized risk score model for early SVG occlusion could address this unmet need, eg, by personalized early postoperative administration of dual antiplatelet treatment or aggressive lipid-lowering treatment to high-risk patients ${ }^{12}$ to improve clinical outcomes, quality of life, and related health care costs post-CABG. Since the risk factors for early SVG occlusion remain unknown, we used an individual patient data (IPD) meta-analysis to develop a predictive model for early SVG occlusion.

\section{MATERIAL AND METHODS \\ Study Design and Objectives}

The design of the study is summarized in the Figure 1.

Arm A: Systematic review of the literature for early SVG occlusion. Published literature in MEDLINE was systematically searched for studies describing the incidence of SVG occlusion during the first year post-CABG to provide an accurate estimation of early SVG occlusion.

Arm B: IPD meta-analysis and prediction model development. The SAFINOUS-CABG Consortium (Saphenous Vein Graft Failure-An Outcomes Study in Coronary Artery Bypass Grafting) is an international collaboration between cardiothoracic centers that has been formed with the aim to share IPD. By using IPD, a prediction model for early SVG occlusion was developed and internally validated in a derivation cohort ( $\mathrm{n}=1492$ patients), which was subsequently tested in the validation cohort $(n=372)$. The aim was to construct a risk score for the individualized prediction of early graft occlusion that could be used as a clinical tool.

\section{Literature Search and Study Eligibility}

Eligibility criteria. Eligibility criteria for including studies using the PICOS approach were as follows. Types of studies: clinical cohorts, registries, or randomized clinical trials; types of participants: patients with established coronary disease; types of interventions: CABG operation; types of outcome measures: the primary outcome was SVG occlusion within the first year post-CABG (assessed either by invasive angiography or by computed tomography angiography). No secondary outcomes were assessed.

Search methods for identification of studies. Published literature was assessed by 2 independent reviewers (A.A. and E.O.) and then identified studies were further screened by a third independent reviewer (M.H.T.). Eligible studies were drawn from a systematic review of the English literature in Medline database from January 1970 until August 2017. The following medical subject headings (Medical Subject Headings terms) were used: "saphenous vein," "coronary artery bypass," "graft, occlusion," "vascular patency," and "coronary artery disease." Studies were deemed eligible for inclusion if they were full-length publications in peer-reviewed journals, reporting on SVG patency rates within the first year after CABG either by invasive coronary angiography or computed tomography angiography. Graft occlusion was defined as a $100 \%$ stenosis of at least 1 SVG. From a total of 10,332 hits, 48 eligible studies were identified. The Preferred Reporting Items for Systematic Reviews and Meta-Analyses-IPD flow-chart for the study is presented in the Figure E1. The TRIPOD checklist ${ }^{13}$ is also included in the Online Data Supplement.

Measures of treatment effect. Studies may report the incidence of graft failure either as percent of patients enrolled, or as percent of grafts used. The primary outcome was expressed as the percent proportion of SVG occlusion per grafts used, since this information could be more reliably extracted from the aggregate published data. 


\section{Saphenous Vein Graft Failure - An Outcomes Study in Coronary Artery Bypass Grafting}

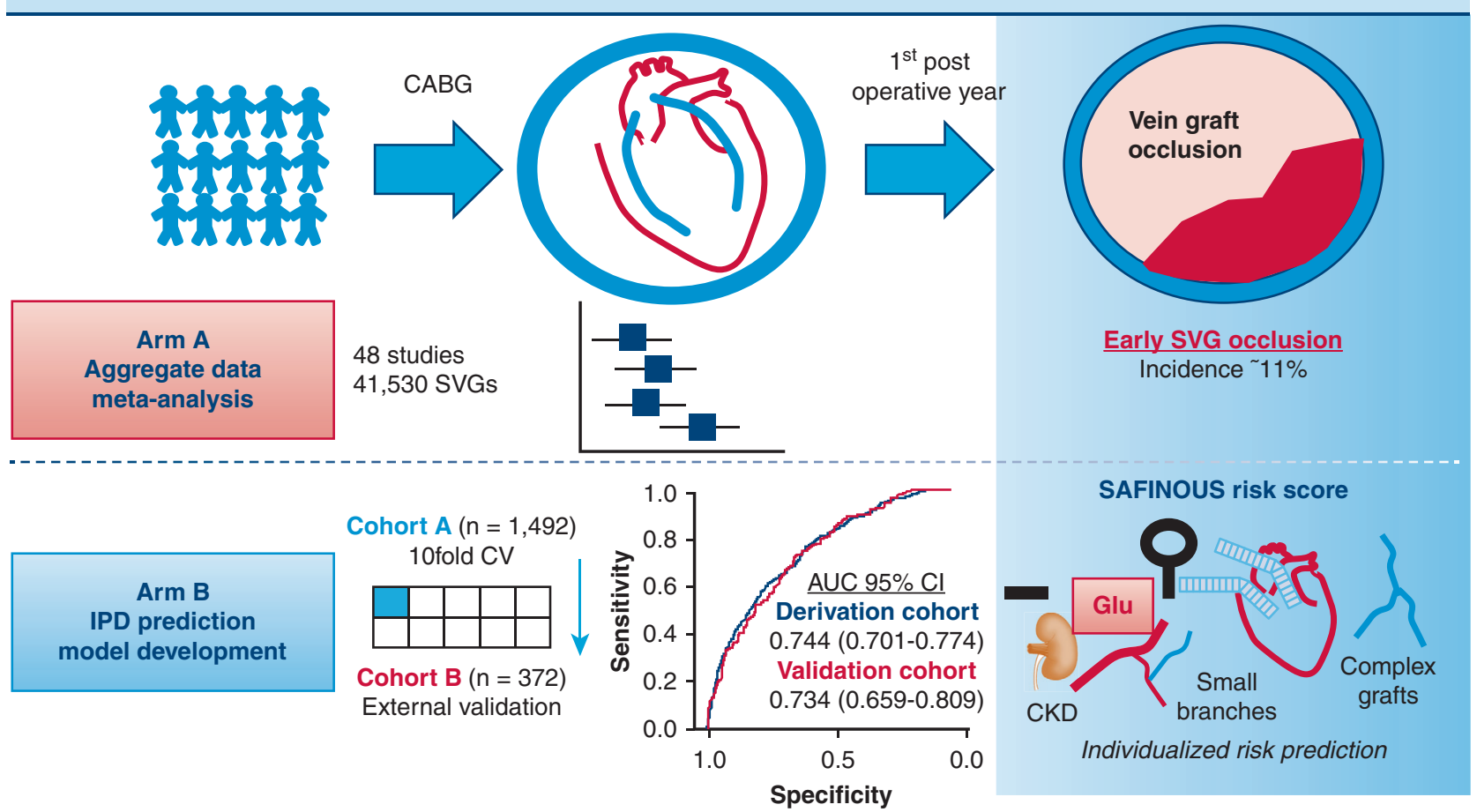

FIGURE 1. Summary of the study design and the main findings of each arm. $C A B G$, Coronary artery bypass grafting; $S V G$, saphenous vein graft; $I P D$, individual patient data; $C V$, coefficient of variation; $A U C$, area under the curve; $C I$, confidence interval; $G l u$, glucose; $C K D$, chronic kidney disease.

\section{Developing a Predictive Model for Early SVG Occlusion Using IPD}

To develop a predictive model for early SVG occlusion, shared IPD was used from the SAFINOUS-CABG Consortium, an international collaboration between cardiothoracic centers with IPD for early SVG patency in patients undergoing CABG. Authors of eligible articles were contacted per e-mail and/or per post with a request to join the SAFINOUS-CABG Consortium and share published and/or unpublished IPD from their center. If we did not receive a response after 2 weeks, the authors were contacted again. From the 48 eligible studies (Table E1),,$^{3-7,14-56}$ we received a response from 8 institutions, and a final of 5 centers that used uniform surgical revascularization strategies were included in the IPD metaanalysis (Table E2). For left anterior descending revascularization, a LIMA graft was used and additional SVGs in the case of significant diagonal disease. The use of composite (ie, SVG Y-grafts or LIMA/SVG grafts) or sequential grafts was overall minimal $(\sim 10 \%)$ and decided by the operating surgeon. Patients routinely received statin and antiplatelet treatment postoperatively as per standard local clinical practice. Participant demographics, patient-related risk factors, procedural details, outcome, and follow-up data were extracted from the received IPD files and aggregated into a database after careful data examination.

\section{Statistical Analysis}

Arm A: Aggregate data meta-analysis. The meta-analysis of the reported proportions of graft occlusion in eligible studies was carried out using a random effects model using the method of DerSimonian and Laird, ${ }^{57}$ with the estimate of heterogeneity being taken from the inverse-variance random-effect model (metaprop command; Stata Statistical Software, Release 13; StataCorp LP, College Station, Tex).
Subgroup and meta-regression analysis were carried out to identify predictors of reported graft occlusion rates (metareg command; Stata). To explore the association between the period of patient enrollment and graft occlusion in meta-regression, a "chronological rank" was assigned to all studies. A random-effects model was used to obtain the pooled incidence of SVG occlusion (and 95\% confidence intervals [CIs]) and illustrated in forest plots. Subgroup analyses were performed for the time of graft patency assessment postsurgery ( $<1$ month, 1 to $<3$ months, 3 to 6 months, or 12 months), the type of surgery performed (on-pump vs off-pump surgery), period of patient enrollment, study location, and study size. The presence of statistical heterogeneity was explored using the $\mathrm{I}^{2}$.

Arm B: IPD predictive model development. The shared IPD contributed to the formation of a database of 1864 patients (2925 SVGs) with complete angiographic follow-up data on early SVG occlusion. The collected demographic characteristics were examined for the extent of missingness. Missing values occurred for several predictors in our dataset, and some variables were systematically missing, meaning they were not collected within specific studies. We therefore applied a multilevel multiple imputation (MLMI) model, which uses generalized linear mixed effect model to simultaneously impute sporadically and systematically missing variables in the setting of IPD meta-analysis. MLMI also fully accounts for between-study heterogeneity within the imputation model. ${ }^{58}$ Simulation studies have shown that MLMI is associated with less bias in predictor effects compared with a complete case analysis-where studies with systematically missing variables are excluded-and MLMI is also associated with less bias than traditional multiple imputation, which ignores heterogeneity across studies. ${ }^{58}$ All variables that were available in at least $70 \%$ of participants across all studies combined were considered for inclusion in the multiple imputation model. Five imputation data sets were generated. 


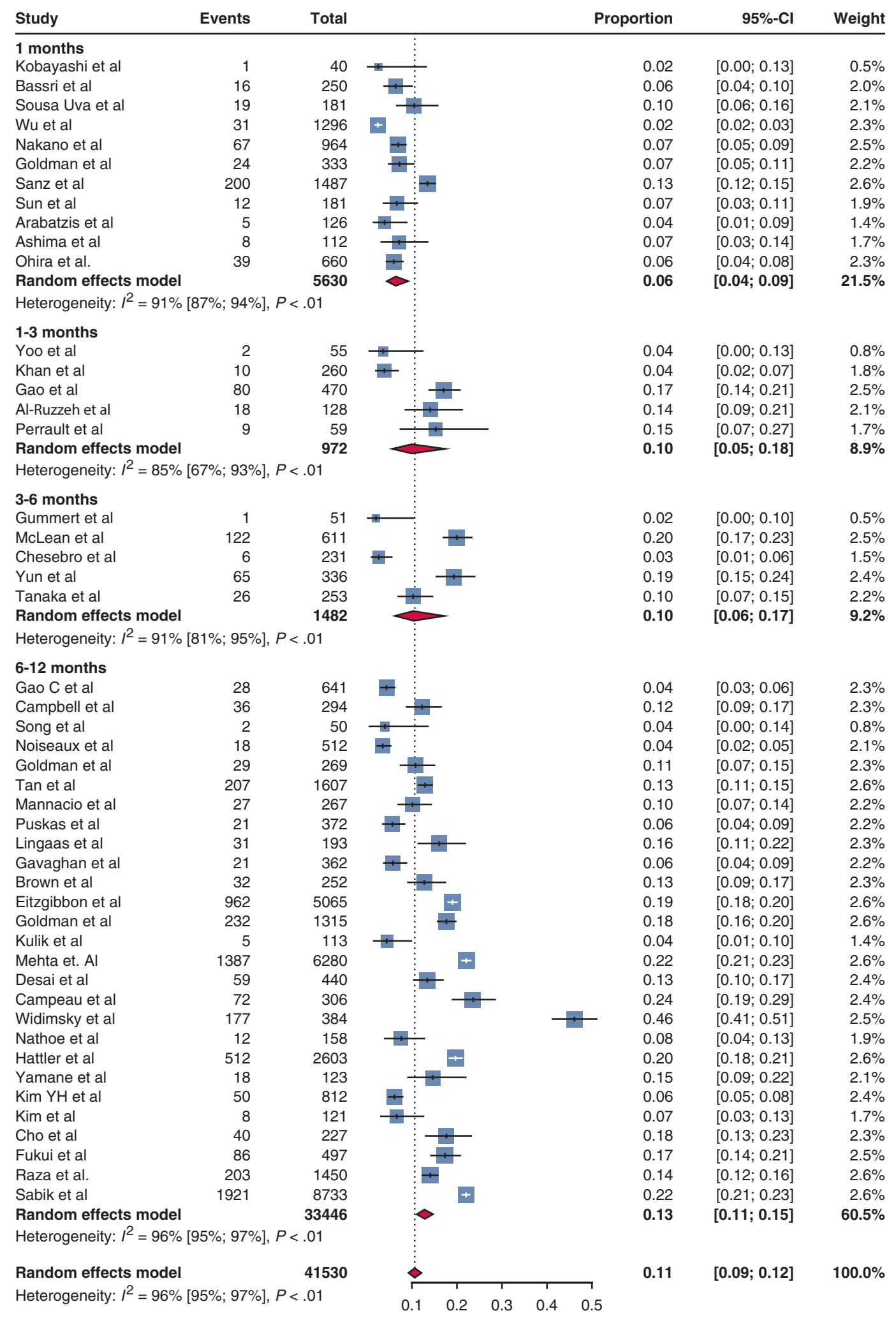

FIGURE 2. Early saphenous vein graft occlusion in published literature. Forest plot of published studies for the incidence of saphenous vein graft occlusion during the first 12 months post-coronary artery bypass grafting. The size of the squares corresponds to the weight of each study. The diamonds and their width represent the pooled weighted effect size and the $95 \%$ confidence intervals $(C I)$, respectively. 


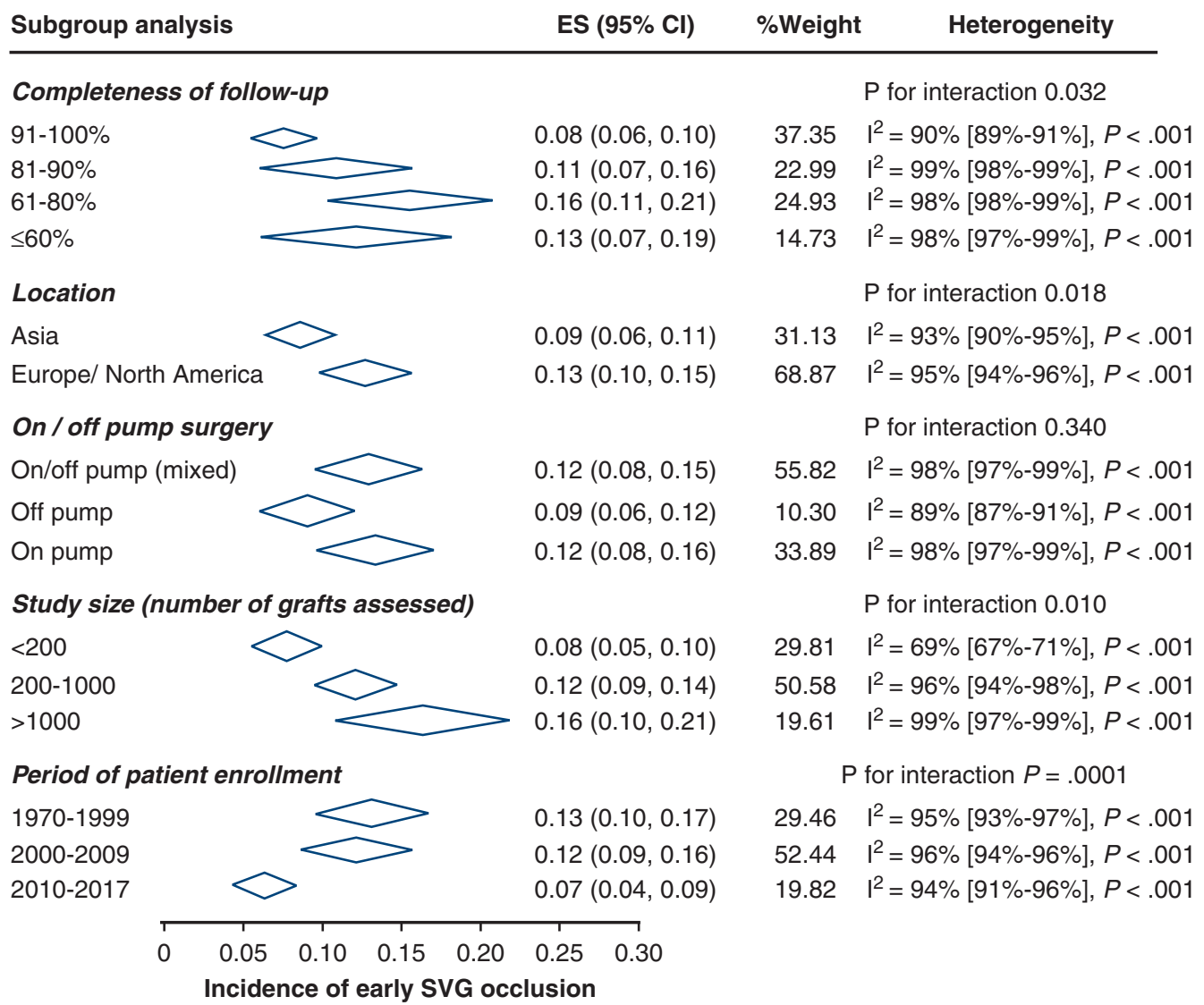

A

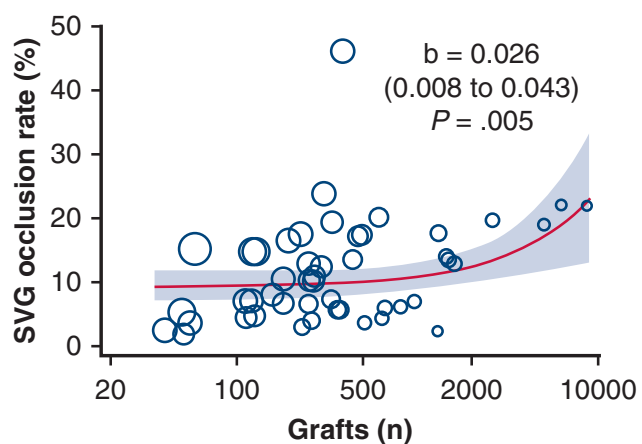

B

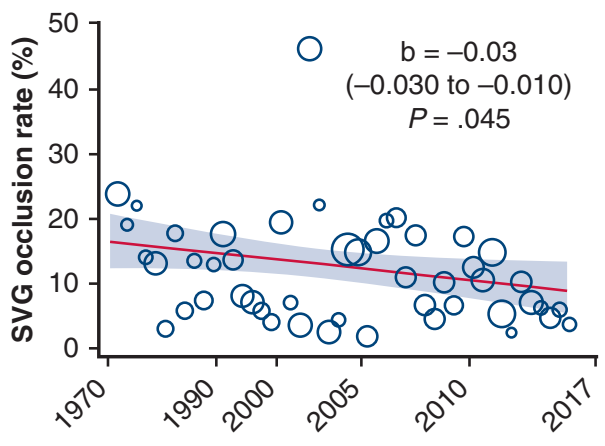

Period of patient enrolment

C

FIGURE 3. Subgroup analysis for the aggregate data meta-analysis. Subgroup analysis for completeness of angiographic follow-up, study location, on/offpump surgery, study size, and period of patient enrollment (A). Meta-regression and bubble plots for the association between the incidence of graft occlusion and study size (number of grafts assessed, B) or the period of patient enrollment (chronological ranking of studies, C). The size of the circles represents the weight of each study on the pooled estimate for graft occlusion. ES, Effect size; $C I$, confidence interval; SVG, saphenous vein graft.

The population of the SAFINOUS-CABG Consortium was split using a random seed into a derivation $(80 \%, \mathrm{n}=1492$ patients) and validation $(20 \%, \mathrm{n}=372$ patients) cohort for prediction of SVG occlusion (caret package, $\mathrm{R}$ project). The derivation cohort was used for model development and internal 10-fold cross-validation (and an optimism-adjusted c-index was also calculated), whereas the validation cohort served for the validation of the developed model. All variables included in the imputation model were included in a generalized logistic random effects model (lme4 $\mathrm{R}$ package) as predictors for graft occlusion within the 1st year post surgery (using a random effect for individual cohorts, ie, surgical sites). A random effects model assumes that patient level observations are not independent as in the case of samples drawn from multiple sites. All remaining predictor 
TABLE 1. Study population demographics

\begin{tabular}{|c|c|c|}
\hline & $\frac{\text { Derivation cohort }}{(\mathrm{n}=1492)}$ & $\frac{\text { Validation cohort }}{(n=372)}$ \\
\hline Age, $y$ & $61.48(8.89)$ & $60.83(9.41)$ \\
\hline Male sex, $\%$ & 78.9 & 82.0 \\
\hline Body mass index, $\mathrm{kg} / \mathrm{m}^{2}$ & $27.25(4.17)$ & $27.49(4.49)$ \\
\hline Hypertension, $\%$ & 62.7 & 62.4 \\
\hline Dyslipidemia, \% & 69.2 & 67.7 \\
\hline Diabetes, $\%$ & 22.6 & 22.3 \\
\hline Active smoking, $\%$ & 25.8 & 22.3 \\
\hline \multicolumn{3}{|l|}{ NYHA class, $\%$} \\
\hline I & 48.5 & 46.8 \\
\hline II & 37.2 & 39.7 \\
\hline III & 10.9 & 10.5 \\
\hline IV & 3.4 & 3.0 \\
\hline $\mathrm{LVEF}<50 \%, \%$ & 30.8 & 31.5 \\
\hline \multicolumn{3}{|l|}{ Number of VD, $\%$} \\
\hline 1 & 1.2 & 1.3 \\
\hline 2 & 18.8 & 18.9 \\
\hline 3 & 80.0 & 79.8 \\
\hline Creatinine, $\mathrm{mg} / \mathrm{dL}$ & $1.03(0.33)$ & $1.03(0.36)$ \\
\hline Endoscopic harvesting, $\%$ & 20.7 & 22.2 \\
\hline On pump, $\%$ & 45.8 & 45.7 \\
\hline \multicolumn{3}{|l|}{ Number of SVGs, \% } \\
\hline 1 & 53.8 & 55.1 \\
\hline 2 & 37.2 & 37.4 \\
\hline 3 & 7.5 & 6.2 \\
\hline$\geq 4$ & 1.5 & 1.4 \\
\hline Complex SVGs, $\%$ & 9.8 & 10.4 \\
\hline Target vessel diagonal, $\%$ & 28.0 & 27.5 \\
\hline LCx/OM, \% & 52.8 & 52.1 \\
\hline RCA, \% & 74.1 & 76.6 \\
\hline Occlusion ( $\%$ patients $)$ & 13.7 & 13.7 \\
\hline
\end{tabular}

Continuous variables presented as mean \pm standard deviation. NYHA, New York Heart Association; $L V E F$, left ventricular ejection fraction; $V D$, vessel disease; $S V G$, saphenous vein graft; $L C x$, left circumflex; $O M$, obtuse marginal; $R C A$, right coronary artery.

variables were introduced as fixed effects. The model included demographic variables (age, sex, body mass index), cardiovascular risk factors (hypertension, dyslipidemia, diabetes mellitus, smoking), clinical scores (ie, New York Heart Association class), laboratory/diagnostic (preoperative serum creatinine levels, left ventricular ejection fraction, number of diseased vessels), and procedural characteristics (endoscopic vein harvesting, on/off-pump operation, use of complex, ie, composite or sequential, grafts, number of grafts, and target vessel type). All continuous predictors were included as linear terms in the regression model because this was found to be a good approximation based on assessment for nonlinearity using fractional polynomials. The discriminatory performance of prediction models was assessed using the c-index. Model calibration was assessed graphically using a calibration plot and a smoothed loess estimator.

The final model was used for the construction of the SAFINOUS risk score by following the method described by Sullivan and colleagues ${ }^{59}$
TABLE 2. Independent predictors for early saphenous vein graft occlusion in the final model

\begin{tabular}{lccc}
\hline \multicolumn{1}{c}{ Characteristics } & Coding & $\begin{array}{c}\text { Regression } \\
\text { coefficients }\end{array}$ & $\begin{array}{c}\text { Odds ratio } \\
(\mathbf{9 5} \% \text { CI })\end{array}$ \\
\hline Age, y & - & 0.015 & $1.02(1.01-1.02)$ \\
\hline Sex & Male & -0.632 & $0.53(0.46-0.62)$ \\
\hline Dyslipidemia & - & 0.284 & $1.33(1.14-1.55)$ \\
\hline Diabetes mellitus & - & 0.361 & $1.43(1.25-1.65)$ \\
\hline Active smoking & - & 0.452 & $1.57(1.35-1.82)$ \\
\hline Creatinine, mg/dL & - & 0.546 & $1.73(1.46-2.04)$ \\
\hline Harvesting technique & EVH & -0.426 & $0.65(0.51-0.83)$ \\
\hline Complex grafts & - & 0.632 & $1.88(1.58-2.24)$ \\
\hline Graft in diagonal & - & 0.643 & $1.90(1.57-2.30)$ \\
\hline Graft in LCx/OM & - & 0.615 & $1.85(1.50-2.28)$ \\
\hline Graft in RCA & - & 0.386 & $1.47(1.22-1.78)$ \\
\hline Number of SVG & - & 0.291 & $1.34(1.12-1.60)$ \\
\hline Intercept & & -4.58 & \\
\hline CI Confing & &
\end{tabular}

$C I$, Confidence interval; $E V H$, endoscopic vein harvesting; $L C x$, left circumflex artery; $O M$, obtuse marginal; $R C A$, right coronary artery; $S V G$, saphenous vein graft.

previously used in the development of the Framingham risk score system. To summarize in brief, points were assigned to each variable using as 1 point the risk related with a 10-year increment in age (constant $\mathrm{B}=10 \times 0.015=0.15$ ) and rounded to the nearest integer. Continuous variables were categorized, and each category was assigned point scores based on the distance of each category from the reference one. Points were assigned to each variable by considering the beta coefficients of the final model. The performance of the model across patient subgroups was explored using ipdover and ipdmetan commands in Stata All analyses were completed with R (www.r-project.org; version 3.2.4) and Stata version 13.0 (StataCorp LP).

\section{RESULTS}

\section{Incidence of Early SVG Occlusion in Published Literature}

Among 10,332 abstracts identified with our literature search strategy, a total of 48 clinical studies met the eligibility criteria. The incidence of SVG occlusion and the detailed characteristics of the identified studies ${ }^{3-7,14-56}$ are presented in Table E1. In the meta-analysis of aggregate published data (Figure 2), the pooled estimate for SVG occlusion rate was $6 \%$ of grafts at 1 month (data on 13,944 grafts) and $13 \%$ of grafts at 12 months (data on 33,446 grafts). The estimated risk of SVG occlusion within the first year post-CABG was $11 \%$ of grafts (data on 41,530 grafts). There was significant heterogeneity between studies $\left(\mathrm{I}^{2}=98 \%, P<.001\right)$, which was partly explained by differences in the completeness of angiographic follow-up, study location, study size, and period of patient enrollment (Figure 3, A). In more recent studies (period of patient enrolment after 2010), the incidence of early SVG occlusion was estimated at $7 \%$. Similar results were identified in meta-regression analysis, where there was a significant 


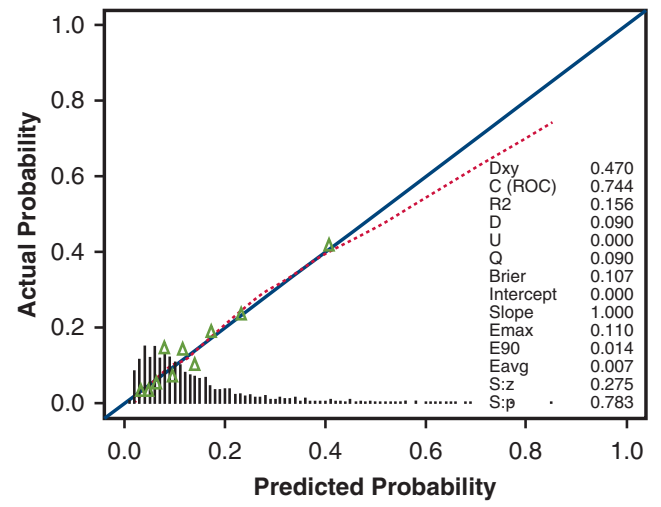

A

- Ideal … Nonparametric $\Delta$ Grouped observations

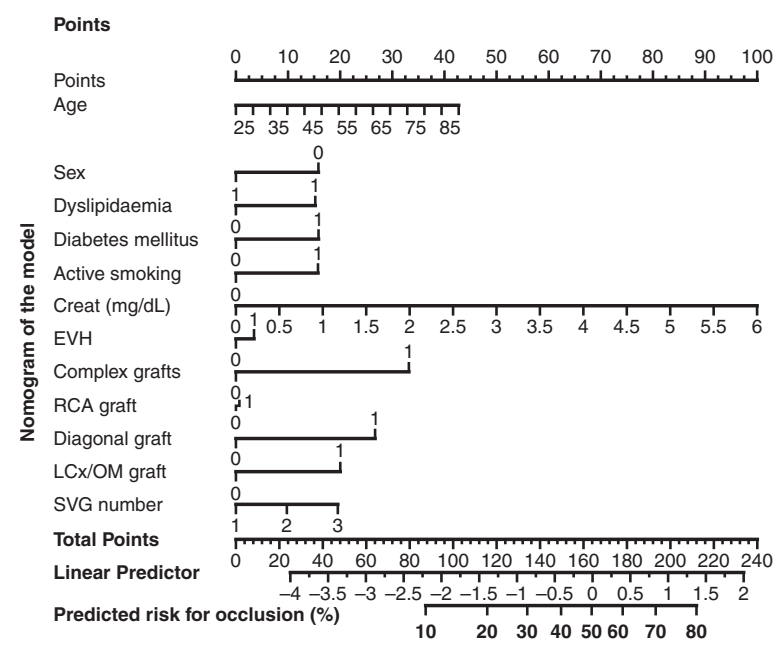

D

B

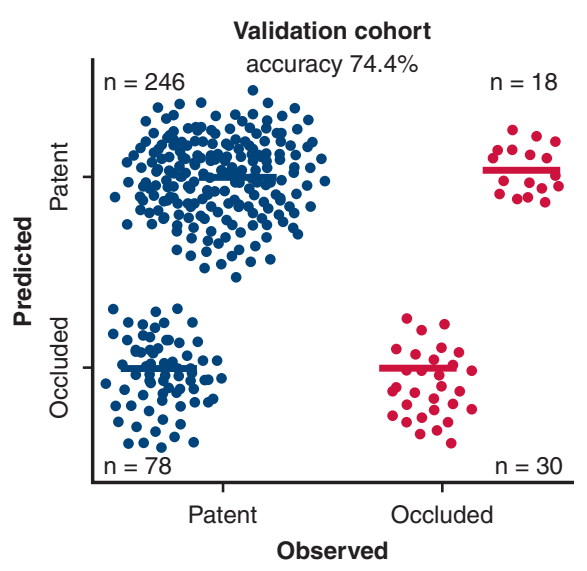

C
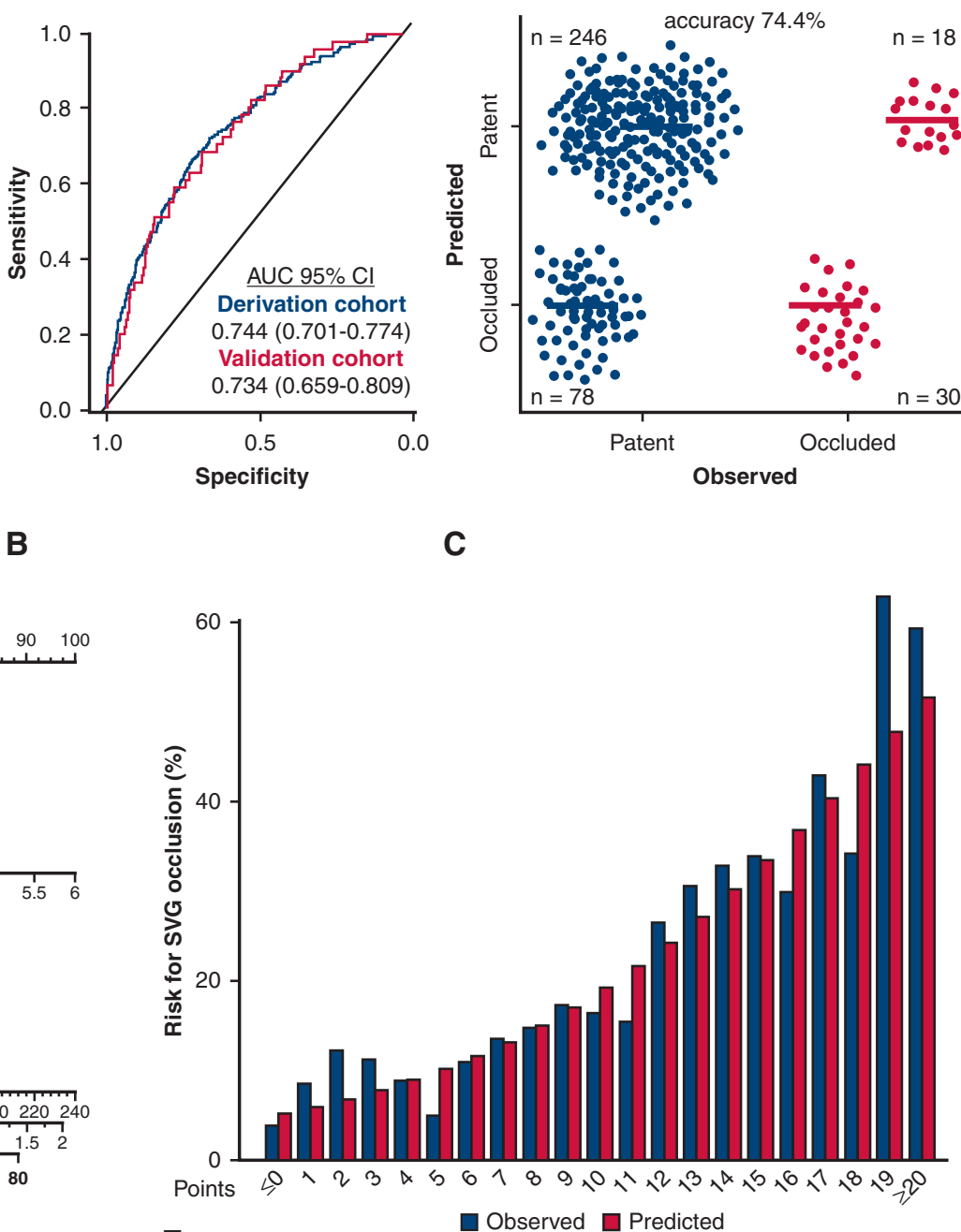

E

FIGURE 4. Development of a predictive model for early saphenous vein graft ( $S V G)$ occlusion. Calibration curve and goodness of fit for the developed prediction model for SVG occlusion (A) and area under the curve (AUC) for model's performance in derivation and validation cohorts (B). Confusion matrix for predicted versus observed SVG occlusion in the validation cohort based on the developed model (C). Nomogram for predicting the risk for early SVG occlusion from the developed model (D). Observed and predicted probabilities for SVG occlusion across strata of the constructed SAFINOUS score, derived from the final predictive model (E). $C I$, Confidence interval; $E V H$, endoscopic vein harvesting; $R C A$, right coronary artery; $L C x$, left circumflex artery; $O M$, obtuse marginal; $S V G$, saphenous vein graft.

association of graft occlusion with larger and older studies (Figure 3, $B$ and $C$ ) cohorts in the field. In multivariate meta-regression analysis, the size of the study, the date of the cohort, and the time point of graft patency assessment post-CABG could explain $16.4 \%$ of between-study variance.

\section{IPD Meta-Analysis and Prediction Modeling for Early SVG Occlusion}

For the SAFINOUS-CABG Consortium IPD, the detailed demographic characteristics of the population included in the derivation and validation cohorts are summarized in Table 1 (the individual cohorts contributing to the shared IPD are shown in Table E2). In multivariate analysis age, sex, body mass index, dyslipidemia, diabetes mellitus, active smoking, preoperative creatinine levels, on-pump surgery, endoscopic vein harvesting, use of complex grafts, target vessel type, and SVG number were identified as independent predictors for SVG occlusion during the first year post-CABG (Table 2). The final constructed model had good performance for prediction of early SVG occlusion in the derivation cohort (c-index $=0.744 ; 95 \%$ CI, 0.701-0.774). In 10-fold cross-validation (Figure E2) the optimism-adjusted c-statistics was consistent (adjusted 
TABLE 3. Predictors from logistic regression used in the construction of the SAFINOUS score

\begin{tabular}{|c|c|c|c|c|c|c|}
\hline Variable & Categories & Reference & $\mathbf{W}_{\mathrm{ij}}$ & $\beta_{\mathrm{i}}$ & $\beta_{\mathrm{i}}\left(\mathbf{W}_{\mathrm{ij}}-\mathbf{W}_{\mathrm{iref}}\right)$ & Points \\
\hline \multirow[t]{6}{*}{ Age, $y$} & $30-39$ & 34.5 & $\mathrm{~W}_{\text {lref }}$ & 0.015 & -0.30 & -2 \\
\hline & $40-49$ & 44.5 & & & -0.15 & -1 \\
\hline & $50-59$ & 54.5 & & & 0 & 0 \\
\hline & $60-69$ & 54.5 & & & 0.15 & 1 \\
\hline & $70-79$ & 74.5 & & & 0.30 & 2 \\
\hline & $80-89$ & 84.5 & & & 0.45 & 3 \\
\hline Sex & & Male & $\mathrm{W}_{2 \text { ref }}$ & -0.632 & -0.632 & -3 \\
\hline Dyslipidemia & & & $\mathrm{W}_{4 \mathrm{ref}}$ & 0.284 & 0.284 & 1 \\
\hline Diabetes & & & $\mathrm{W}_{\text {5ref }}$ & 0.361 & 0.361 & 3 \\
\hline Active smoking & & & $\mathrm{W}_{6 \mathrm{ref}}$ & 0.452 & 0.452 & 3 \\
\hline \multirow[t]{5}{*}{ Creatinine, $\mathrm{mg} / \mathrm{dL}$} & $0.50-0.99$ & 0.75 & $\mathrm{~W}_{7 \mathrm{ref}}$ & 0.546 & -0.273 & -2 \\
\hline & $1.00-1.49$ & 1.25 & & & 0 & 0 \\
\hline & $1.50-1.99$ & 1.75 & & & 0.273 & 2 \\
\hline & $2.00-2.49$ & 2.25 & & & 0.546 & 4 \\
\hline & $\geq 2.50$ & 3.50 & & & 1.229 & 8 \\
\hline Endoscopic harvesting & & & $W_{9 \text { ref }}$ & -0.426 & -0.426 & -3 \\
\hline Complex grafts & & & $\mathrm{W}_{10 \mathrm{ref}}$ & 0.632 & 0.632 & 4 \\
\hline \multirow[t]{3}{*}{ Number of SVG } & 1 & 1 & $\mathrm{~W}_{11 \text { ref }}$ & 0.291 & 0 & 0 \\
\hline & 2 & 2 & & & 0.291 & 2 \\
\hline & $\geq 3$ & 3 & & & 0.582 & 4 \\
\hline Graft in diagonal & & & $\mathrm{W}_{12 \mathrm{ref}}$ & 0.643 & 0.643 & 4 \\
\hline Graft in $\mathrm{LCx} / \mathrm{OM}$ & & & $\mathrm{W}_{13 \mathrm{ref}}$ & 0.615 & 0.615 & 4 \\
\hline Graft in RCA & & & $\mathrm{W}_{14 \mathrm{ref}}$ & 0.386 & 0.386 & 3 \\
\hline
\end{tabular}

Points were assigned to each variable using as 1 point the risk related with a 10 -year increment in age (constant $\mathrm{B}=10 \times 0.015=0.15$ ) and rounded to nearest integer. $S V G$, Saphenous vein graft; $L C x$, left circumflex artery; $O M$, obtuse marginal; $R C A$, right coronary artery.

c-index: 0.732). In the validation cohort the model also had good performance (c-index $=0.734 ; 95 \% \mathrm{CI}, 0.7659$ 0.801 , Figure $4, B$ ), and a predictive accuracy of $74.4 \%$ for SVG occlusion based on the optimal cut-off (Figure 4, C). A nomogram for predicting early SVG occlusion from the developed full clinical model is presented in Figure 4, D.

\section{SAFINOUS Score: A Novel Risk Score for Early SVG Occlusion}

Based on the final model for SVG occlusion (Table 2), risk score points were assigned to each predictor (Table 3), to construct a risk score system. The SAFINOUS score comprised 12 risk variables: (1) demographic characteristics (age, sex), (2) clinical risk factors (dyslipidemia, diabetes, active smoking), (3) laboratory findings (preoperative creatinine levels), and (4) operative characteristics (endoscopic vein harvesting, use of complex grafts, target vessel types [graft in diagonal, graft in left circumflex, graft in right coronary artery], and number of SVGs). The
SAFINOUS risk score performed similarly well compared with the original model for prediction of SVG occlusion (c-index $=0.700 ; 95 \%$ CI, 0.684-0.716). For a classification cut-off of 0.25 in logistic regression, the SAFINOUS score correctly classified $83.7 \%$ of patients assessed (sensitivity 27\%, specificity 93\%, positive predictive value $37 \%$, negative predictive value $90 \%$ ). The predicted and observed probabilities across different points of the SAFINOUS score are presented in Figure 4, E. In subgroup analysis SAFINOUS score retained its predictive value for SVG occlusion across all patient subgroups (Figure 5).

\section{DISCUSSION}

This study provides a comprehensive prediction model for early SVG occlusion. We first showed that based on aggregate data from 48 studies, the pooled incidence of SVG occlusion within the first year post-CABG is estimated at $11 \%$, whereas it is significantly lower with modern surgical practice techniques, estimated at 


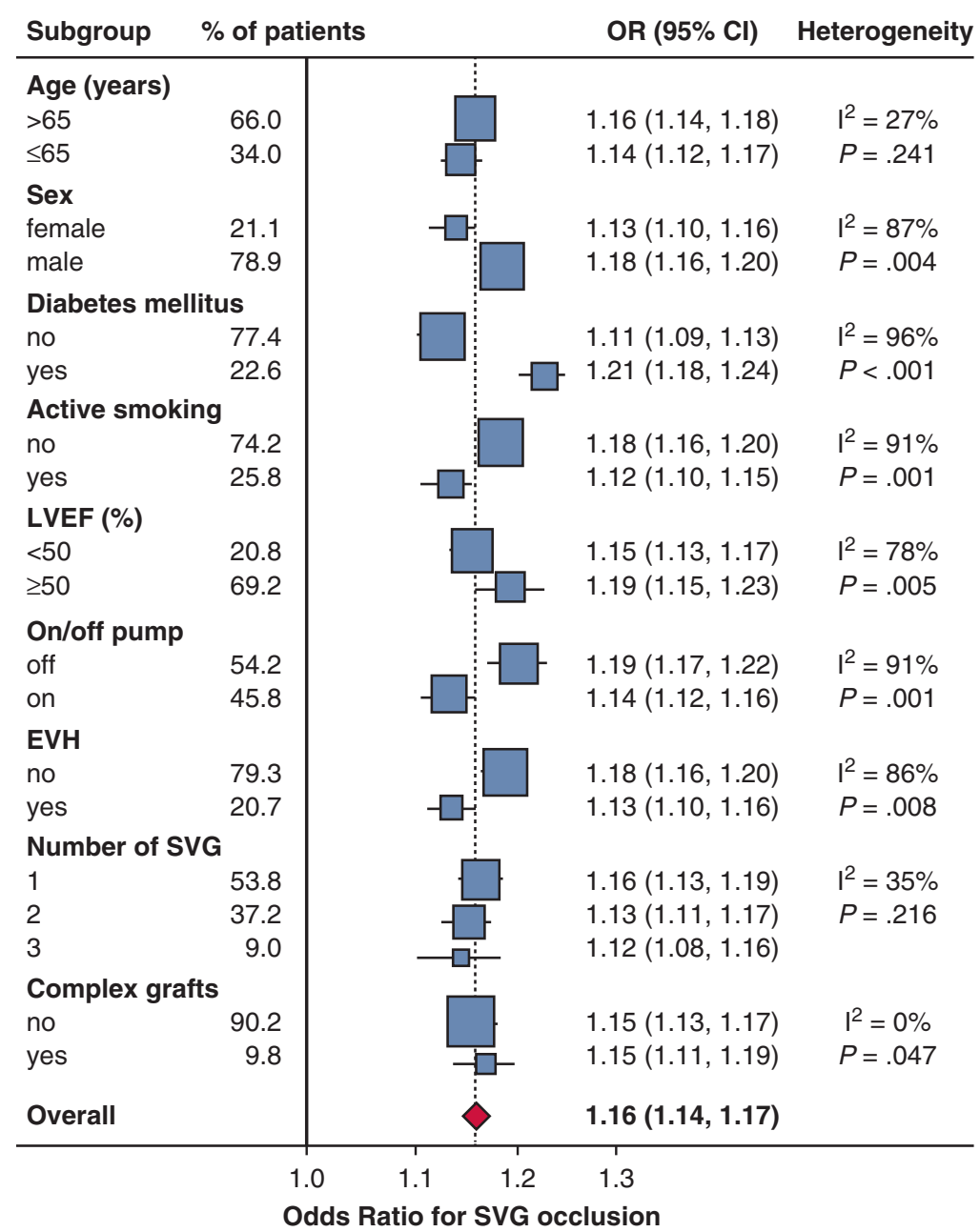

FIGURE 5. Predictive value of SAFINOUS score for early saphenous vein graft occlusion across patient subgroups. $O R$, Odds ratio; $C I$, confidence interval; $L V E F$, left ventricular ejection fraction; $E V H$, endoscopic vein harvesting; $S V G$, saphenous vein graft.

$7 \%$-in studies with period of patient enrollment after 2010. Then by using IPD, we developed and validated a predictive model, which was used to construct the SAFINOUS score, a 12-variable risk score point system, for the calculation of the individualized risk for early SVG occlusion in patients undergoing CABG. Taken together, our findings (Figure 1) could contribute to the risk stratification of patients for early SVG occlusion, guide operation planning as well as the postoperative patient management and the deployment of tailored, preventive therapeutic strategies (Video 1).

CABG is the gold-standard revascularization strategy for patients with complex multivessel coronary artery disease, since it reduces mortality and major adverse cardiac events and improves the quality of life of patients. ${ }^{60}$ Nevertheless, the efficacy of CABG is hampered by the high occlusion rates of SVGs, estimated as high as $43 \%$ at 10 years.
SVG occlusion has a negative impact on the quality of life of patients ${ }^{61}$ and poses an extra economic burden to health care systems. SVG occlusion leads to recurrent angina symptoms, heart failure development, and significantly poorer clinical outcomes in the setting of acute myocardial infarction compared with native vessel disease. ${ }^{62}$ Revascularization of occluded SVGs is also challenging and has a high rate of complications. ${ }^{62}$

In contrast to late SVG occlusion (which is due to atherosclerosis development) early SVG occlusion is attributed to graft thrombosis or accelerated intimal hyperplasia, developed rapidly when the SVG is exposed to arterial circulation. ${ }^{1}$ Although prediction models have been constructed for late graft disease (ie, SVG atherosclerosis), ${ }^{4}$ the factors associated with the risk of early SVG occlusion have not been systematically evaluated, and a widely accepted comprehensive prediction model for early SVG occlusion 


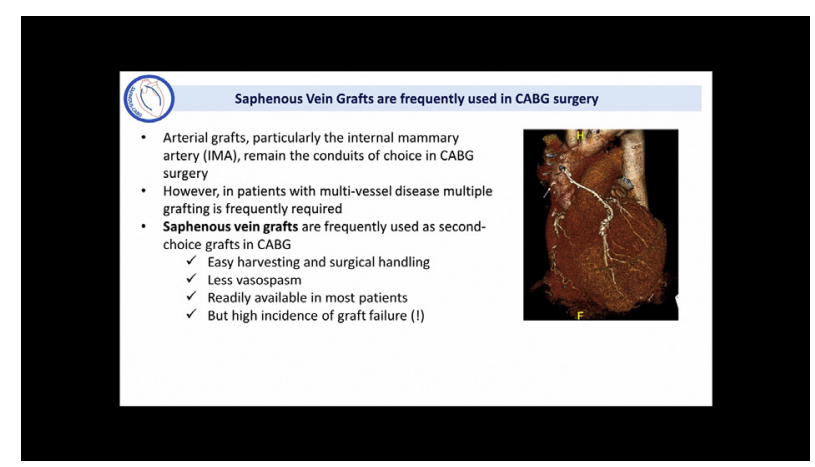

VIDEO 1. The main findings and implications of the study are summarized in this online video by Dr Antonopoulos. Video available at: https://www.jtcvs.org/article/S0022-5223(19)31640-X/fulltext.

had been lacking. We have now developed and validated a prediction model for graft occlusion within the first-year post-CABG by using multicenter IPD. We have identified clinical, technical, and perioperative predictors for early SVG occlusion. Female sex is independently associated with early SVG occlusion, as previously shown, ${ }^{6}$ possibly due to the smaller vessel size of female subjects. Cardiovascular risk factors, eg, diabetes, dyslipidemia, smoking, and chronic kidney disease ${ }^{63}$ also raise the risk for early SVG occlusion. The use of complex grafts, grafting of secondary coronary branches, and the harvesting technique were also independent risk factors for graft occlusion. Although previous reports suggest greater rates of graft failure with endoscopic vein harvesting, ${ }^{64}$ within the SAFINOUS-CABG IPD Consortium endoscopic vein harvesting was associated with reduced risk for occlusion. This could reflect the experienced harvesters employed in the centers of the Consortium.

The presented SAFINOUS score is the first comprehensive attempt to develop a prediction model for early graft occlusion that could be used for the risk stratification of patients undergoing CABG. The proposed SAFINOUS score could be used as a clinical decision-making tool to estimate the personalized risk for early SVG occlusion. Assessment of SAFINOUS score could help in surgery planning preoperatively (eg, total arterial revascularization) or the tailored administration of aggressive treatment postoperatively (eg, dual antiplatelet therapy) as a more cost-effective strategy to reduce cardiovascular events and bleeding complications.

Certain limitations of our study should be acknowledged. First, the developed model may not account for possible residual confounding or unchecked interactions and is subject to selection bias (typical for observational studies). The absence of data on storage solutions and grafting of small target vessels are also weaknesses of the developed model. Future iterations of the model in a larger cohort with available biological data on harvested SVGs could be used to evaluate the incremental value of biological factors for prediction of graft failure on top of the constructed SAFINOUS score. Finally, although a rigorous statistical approach was used to develop the model, including internal and external validation, stronger forms of validation may be required. For example, future validation studies from diverse geographic regions, with different population background and operation strategies, as well as full independent validation by independent investigators would be welcome.

\section{CONCLUSIONS}

We conducted a systematic review of the published literature for the incidence of early SVG occlusion and present the first comprehensive prediction model for early SVG occlusion based on a large multicenter cohort of patients undergoing CABG. SAFINOUS score is a 12-variable risk score point system that independently predicts early SVG occlusion across all patient subgroups and could be used in clinical practice to identify high-risk individuals for reduced graft patency. SAFINOUS score could contribute to the design of clinical studies to test the effectiveness of tailored dual antiplatelet and/or aggressive lipid lowering treatment in patients at high risk for early graft occlusion or the efficacy of novel therapeutic strategies.

\section{Conflict of Interest Statement}

Authors have nothing to disclose with regard to commercial support.

We are grateful to Mr Panagiotis Antonopoulos for his contribution in the creation of the online video.

\section{References}

1. Motwani JG, Topol EJ. Aortocoronary saphenous vein graft disease: pathogenesis, predisposition, and prevention. Circulation. 1998;97:916-31.

2. Gaudino M, Antoniades C, Benedetto U, Deb S, Di Franco A, Di Giammarco G, et al. Mechanisms, consequences, and prevention of coronary graft failure. Circulation. 2017;136:1749-64.

3. Fitzgibbon GM, Kafka HP, Leach AJ, Keon WJ, Hooper GD, Burton JR. Coronary bypass graft fate and patient outcome: angiographic follow-up of 5,065 grafts related to survival and reoperation in 1,388 patients during 25 years. $J$ Am Coll Cardiol. 1996;28:616-26.

4. Raza S, Blackstone EH, Houghtaling PL, Rajeswaran J, Riaz H, Bakaeen FG, et al. Influence of diabetes on long-term coronary artery bypass graft patency. J Am Coll Cardiol. 2017;70:515-24.

5. Widimsky P, Straka Z, Stros P, Jirasek K, Dvorak J, Votava J, et al. One-year coronary bypass graft patency: a randomized comparison between off-pump and onpump surgery angiographic results of the PRAGUE-4 trial. Circulation. 2004; 110:3418-23.

6. McLean RC, Nazarian SM, Gluckman TJ, Schulman SP, Thiemann DR, Shapiro EP, et al. Relative importance of patient, procedural and anatomic risk factors for early vein graft thrombosis after coronary artery bypass graft surgery J Cardiovasc Surg (Torino). 2011;52:877-85.

7. Tan ES, van der Meer J, Jan de Kam P, Dunselman PH, Mulder BJ, Ascoop CA, et al. Worse clinical outcome but similar graft patency in women versus men one 
year after coronary artery bypass graft surgery owing to an excess of exposed risk factors in women. CABADAS. Research group of the Interuniversity Cardiology Institute of The Netherlands. Coronary artery bypass graft occlusion by aspirin, dipyridamole and acenocoumarol/phenoprocoumon study. J Am Coll Cardiol. 1999;34:1760-8.

8. Takagi H, Matsui M, Umemoto T. Lower graft patency after off-pump than onpump coronary artery bypass grafting: an updated meta-analysis of randomized trials. J Thorac Cardiovasc Surg. 2010;140:e45-7.

9. Verma S, Goodman SG, Mehta SR, Latter DA, Ruel M, Gupta M, et al. Should dual antiplatelet therapy be used in patients following coronary artery bypass surgery? A meta-analysis of randomized controlled trials. BMC Surg. 2015;15: 112 .

10. van Diepen S, Fuster V, Verma S, Hamza TH, Siami FS, Goodman SG, et al. Dual antiplatelet therapy versus aspirin monotherapy in diabetics with multivessel disease undergoing CABG: FREEDOM insights. J Am Coll Cardiol. 2017;69: 119-27.

11. Sousa-Uva M, Storey R, Huber K, Falk V, Leite-Moreira AF, Amour J, et al. Expert position paper on the management of antiplatelet therapy in patients undergoing coronary artery bypass graft surgery. Eur Heart J. 2014; 35:1510-4.

12. Eisen A, Cannon CP, Blazing MA, Bohula EA, Park JG, Murphy SA, et al. The benefit of adding ezetimibe to statin therapy in patients with prior coronary artery bypass graft surgery and acute coronary syndrome in the IMPROVE-IT trial. Eur Heart J. 2016;37:3576-84.

13. Collins GS, Reitsma JB, Altman DG, Moons KG, Group T. Transparent reporting of a multivariable prediction model for individual prognosis or diagnosis (TRIPOD): the TRIPOD statement. The TRIPOD group. Circulation. 2015; $131: 211-9$

14. Al-Ruzzeh S, George S, Bustami M, Wray J, Ilsley C, Athanasiou T, et al. Effect of off-pump coronary artery bypass surgery on clinical, angiographic, neurocognitive, and quality of life outcomes: randomised controlled trial. BMJ. 2006;332: 1365.

15. Arampatzis CA, Chourmouzi D, Boulogianni G, Lemos P, Pentousis D, Potsi S, et al. Graft failure prior to discharge after coronary artery bypass surgery: a prospective single-centre study using dual 64-slice computed tomography. EuroIntervention. 2016;12:e972-8.

16. Bassri H, Salari F, Noohi F, Motevali M, Abdi S, Givtaj N, et al. Evaluation of early coronary graft patency after coronary artery bypass graft surgery using multislice computed tomography angiography. BMC Cardiovasc Disord. 2009; 9:53.

17. Brown BG, Cukingnan RA, DeRouen T, Goede LV, Wong M, Fee HJ, et al. Improved graft patency in patients treated with platelet-inhibiting therapy after coronary bypass surgery. Circulation. 1985;72:138-46.

18. Campbell PG, Teo KS, Worthley SG, Kearney MT, Tarique A, Natarajan A, et al Non-invasive assessment of saphenous vein graft patency in asymptomatic patients. Br J Radiol. 2009;82:291-5.

19. Campeau L, Crochet D, Lesperance J, Bourassa MG, Grondin CM. Postoperative changes in aortocoronary saphenous vein grafts revisited: angiographic studies at two weeks and at one year in two series of consecutive patients. Circulation. 1975;52:369-77.

20. Chesebro JH, Clements IP, Fuster V, Elveback LR, Smith HC, Bardsley WT, et al. A platelet-inhibitor-drug trial in coronary-artery bypass operations: benefit of perioperative dipyridamole and aspirin therapy on early postoperative veingraft patency. N Engl J Med. 1982;307:73-8.

21. Cho KR, Kim JS, Choi JS, Kim KB. Serial angiographic follow-up of grafts one year and five years after coronary artery bypass surgery. Eur J Cardiothorac Surg. 2006;29:511-6

22. Desai ND, Cohen EA, Naylor CD, Fremes SE, Radial Artery Patency Study Investigators. A randomized comparison of radial-artery and saphenous-vein coronary bypass grafts. $N$ Engl J Med. 2004;351:2302-9.

23. Fukui T, Tabata M, Manabe S, Shimokawa T, Takanashi S. Graft selection and one-year patency rates in patients undergoing coronary artery bypass grafting. Ann Thorac Surg. 2010;89:1901-5.

24. Gao C, Liu Z, Li B, Xiao C, Wu Y, Wang G, et al. Comparison of graft patency for off-pump and conventional coronary arterial bypass grafting using 64-slice multidetector spiral computed tomography angiography. Interact Cardiovasc Thorac Surg. 2009;8:325-9.

25. Gao G, Zheng Z, Pi Y, Lu B, Lu J, Hu S. Aspirin plus clopidogrel therapy increases early venous graft patency after coronary artery bypass surgery a single-center, randomized, controlled trial. J Am Coll Cardiol. 2010;56: 1639-43.
26. Gavaghan TP, Gebski V, Baron DW. Immediate postoperative aspirin improves vein graft patency early and late after coronary artery bypass graft surgery. A placebo-controlled, randomized study. Circulation. 1991;83:1526-33.

27. Goldman S, Copeland J, Moritz T, Henderson W, Zadina K, Ovitt T, et al. Saphenous vein graft patency 1 year after coronary artery bypass surgery and effects of antiplatelet therapy. Results of a veterans administration cooperative study. Circulation. 1989;80:1190-7.

28. Goldman S, Copeland J, Moritz T, Henderson W, Zadina K, Ovitt T, et al. Starting aspirin therapy after operation. Effects on early graft patency. Department of veterans affairs cooperative study group. Circulation. 1991;84:520-6.

29. Goldman S, Sethi GK, Holman W, Thai H, McFalls E, Ward HB, et al. Radial artery grafts vs saphenous vein grafts in coronary artery bypass surgery: a randomized trial. JAMA. 2011;305:167-74.

30. Gummert JF, Demertzis S, Matschke K, Kappert U, Anssar M, Siclari F, et al. Six-month angiographic follow-up of the PAS-Port II clinical trial. Ann Thorac Surg. 2006;81:90-6.

31. Hattler B, Messenger JC, Shroyer AL, Collins JF, Haugen SJ, Garcia JA, et al. Off-Pump coronary artery bypass surgery is associated with worse arterial and saphenous vein graft patency and less effective revascularization: results from the veterans affairs randomized on/off bypass (ROOBY) trial. Circulation. 2012; $125: 2827-35$.

32. Khan NE, De Souza A, Mister R, Flather M, Clague J, Davies S, et al. A randomized comparison of off-pump and on-pump multivessel coronary-artery bypass surgery. N Engl J Med. 2004;350:21-8

33. Kim KB, Cho KR, Jeong DS. Midterm angiographic follow-up after off-pump coronary artery bypass: serial comparison using early, 1-year, and 5-year postoperative angiograms. J Thorac Cardiovasc Surg. 2008;135:300-7.

34. Kim YH, Oh HC, Choi JW, Hwang HY, Kim KB. No-touch saphenous vein harvesting may improve further the patency of saphenous vein composite grafts: early outcomes and 1-year angiographic results. Ann Thorac Surg. 2017;103 1489-97.

35. Kobayashi J, Tashiro T, Ochi M, Yaku H, Watanabe G, Satoh T, et al. Early outcome of a randomized comparison of off-pump and on-pump multiple arteria coronary revascularization. Circulation. 2005:112:I338-43.

36. Kulik A, Le May MR, Voisine P, Tardif JC, Delarochelliere R, Naidoo S, et al Aspirin plus clopidogrel versus aspirin alone after coronary artery bypass graft ing: the clopidogrel after surgery for coronary artery disease (CASCADE) trial. Circulation. 2010;122:2680-7

37. Lingaas PS, Hol PK, Lundblad R, Rein KA, Mathisen L, Smith HJ, et al. Clinical and radiologic outcome of off-pump coronary surgery at 12 months follow-up: a prospective randomized trial. Ann Thorac Surg. 2006;81:2089-95.

38. Mannacio VA, Di Tommaso L, Antignan A, De Amicis V, Vosa C. Aspirin plus clopidogrel for optimal platelet inhibition following off-pump coronary artery bypass surgery: results from the CRYSSA (prevention of Coronary arteRY bypaSS occlusion After off-pump procedures) randomised study. Heart. 2012; 98:1710-5.

39. Mehta RH, Ferguson TB, Lopes RD, Hafley GE, Mack MJ, Kouchoukos NT, et al. Saphenous vein grafts with multiple versus single distal targets in patients undergoing coronary artery bypass surgery: one-year graft failure and five-year outcomes from the project of ex-vivo vein graft engineering via transfection (PREVENT) IV trial. Circulation. 2011;124:280-8.

40. Nakano J, Okabayashi H, Noma H, Sato T, Sakata R. Early angiographic evaluation after off-pump coronary artery bypass grafting. J Thorac Cardiovasc Surg. 2013; 146:1119-25.

41. Nathoe HM, van Dijk D, Jansen EW, Suyker WJ, Diephuis JC, van Boven WJ, et al. A comparison of on-pump and off-pump coronary bypass surgery in lowrisk patients. $N$ Engl J Med. 2003;348:394-402.

42. Noiseux N, Stevens LM, Chartrand-Lefebvre C, Soulez G, Prieto I, Basile F, et al. Off-pump versus on-pump coronary artery bypass surgery: graft patency assessment with coronary computed tomographic angiography: a prospective multicenter randomized controlled pilot study. J Thorac Imaging. 2017;32: 370-7.

43. Ohira S, Doi K, Numata S, Yamazaki S, Itatani K, Kawajiri H, et al. Single-centre experience of off-pump multi-vessel coronary artery bypass grafting using proximal suture device. Heart Lung Circ. 2017;26:1105-12.

44. Oshima H, Tokuda Y, Araki Y, Ishii H, Murohara T, Ozaki Y, et al. Predictors of early graft failure after coronary artery bypass grafting for chronic total occlusion. Interact Cardiovasc Thorac Surg. 2016;23:142-9.

45. Perrault LP, Jeanmart H, Bilodeau L, Lesperance J, Tanguay JF, Bouchard D, et al. Early quantitative coronary angiography of saphenous vein grafts for coronary artery bypass grafting harvested by means of open versus endoscopic 
saphenectomy: a prospective randomized trial. J Thorac Cardiovasc Surg. 2004; 127:1402-7.

46. Puskas JD, Williams WH, Mahoney EM, Huber PR, Block PC, Duke PG, et al. Off-pump vs conventional coronary artery bypass grafting: early and 1-year graft patency, cost, and quality-of-life outcomes: a randomized trial. JAMA. 2004;291: 1841-9.

47. Sabik JF III, Lytle BW, Blackstone EH, Houghtaling PL, Cosgrove DM. Comparison of saphenous vein and internal thoracic artery graft patency by coronary system. Ann Thorac Surg. 2005;79:544-51; discussion 544-551.

48. Sanz G, Pajaron A, Alegria E, Coello I, Cardona M, Fournier JA, et al. Prevention of early aortocoronary bypass occlusion by low-dose aspirin and dipyridamole. Grupo Espanol para el Seguimiento del Injerto Coronario (GESIC). Circulation. 1990;82:765-73.

49. Song SW, Sul SY, Lee HJ, Yoo KJ. Comparison of the radial artery and saphenous vein as composite grafts in off-pump coronary artery bypass grafting in elderly patients: a randomized controlled trial. Korean Circ J. 2012;42:107-12.

50. Sousa Uva M, Cavaco S, Oliveira AG, Matias F, Silva C, Mesquita A, et al. Early graft patency after off-pump and on-pump coronary bypass surgery: a prospective randomized study. Eur Heart J. 2010;31:2492-9.

51. Sun JC, Teoh KH, Lamy A, Sheth T, Ellins ML, Jung H, et al. Randomized trial of aspirin and clopidogrel versus aspirin alone for the prevention of coronary artery bypass graft occlusion: the preoperative aspirin and postoperative antiplatelets in coronary artery bypass grafting study. Am Heart J. 2010;160:1178-84.

52. Tanaka A, Ishii H, Oshima H, Shibata Y, Tatami Y, Osugi N, et al. Progression from stenosis to occlusion in the proximal native coronary artery after coronary artery bypass grafting. Heart Vessels. 2016;31:1056-60.

53. Wu H, Wang J, Sun H, Lv B, Wang X, Hu X, et al. Preoperative continuation of aspirin therapy may improve perioperative saphenous venous graft patency after off-pump coronary artery bypass grafting. Ann Thorac Surg. 2015;99:576-80.

54. Yamane Y, Uchida N, Okubo S, Morimoto H, Mukai S. Impact of the size mismatch between saphenous vein graft and coronary artery on graft patency. Gen Thorac Cardiovasc Surg. 2017;65:25-31.

55. Yoo KJ, Choi D, Choi BW, Lim SH, Chang BC. The comparison of the graft patency after coronary artery bypass grafting using coronary angiography and multi-slice computed tomography. Eur J Cardiothorac Surg. 2003;24:86-91; discussion 91.
56. Yun KL, Wu Y, Aharonian V, Mansukhani P, Pfeffer TA, Sintek CF, et al Randomized trial of endoscopic versus open vein harvest for coronary artery bypass grafting: six-month patency rates. J Thorac Cardiovasc Surg. 2005; 129:496-503.

57. DerSimonian R, Laird N. Meta-analysis in clinical trials. Control Clin Trials. 1986; 7:177-88.

58. Jolani S, Debray TP, Koffijberg $H$, van Buuren $S$, Moons KG. Imputation of systematically missing predictors in an individual participant data meta-analysis: a generalized approach using MICE. Stat Med. 2015;34: 1841-63.

59. Sullivan LM, Massaro JM, D'Agostino RB Sr. Presentation of multivariate data for clinical use: the Framingham Study risk score functions. Stat Med. 2004;23: 1631-60.

60. Serruys PW, Morice MC, Kappetein AP, Colombo A, Holmes DR, Mack MJ et al. Percutaneous coronary intervention versus coronary-artery bypass grafting for severe coronary artery disease. N Engl J Med. 2009;360: 961-72.

61. Samano N, Bodin L, Karlsson J, Geijer H, Arbeus M, Souza D. Graft patency is associated with higher health-related quality of life after coronary artery bypass surgery. Interact Cardiovasc Thorac Surg. 2017;24: 388-94.

62. Yap CH, Sposato L, Akowuah E, Theodore S, Dinh DT, Shardey GC, et al. Contemporary results show repeat coronary artery bypass grafting remains a risk factor for operative mortality. Ann Thorac Surg. 2009;87:1386-91.

63. Zhang L, Wu JH, Otto JC, Gurley SB, Hauser ER, Shenoy SK, et al. Interleukin-9 mediates chronic kidney disease-dependent vein graft disease: a role for mast cells. Cardiovasc Res. 2017;113:1551-9.

64. Kodia K, Patel S, Weber MP, Luc JGY, Choi JH, Maynes EJ, et al. Graft patency after open versus endoscopic saphenous vein harvest in coronary artery bypass grafting surgery: a systematic review and meta-analysis. Ann Cardiothorac Surg. 2018;7:586-97.

Key Words: coronary artery bypass grafting, saphenous vein graft, individual patient meta-analysis, patency, prediction model 


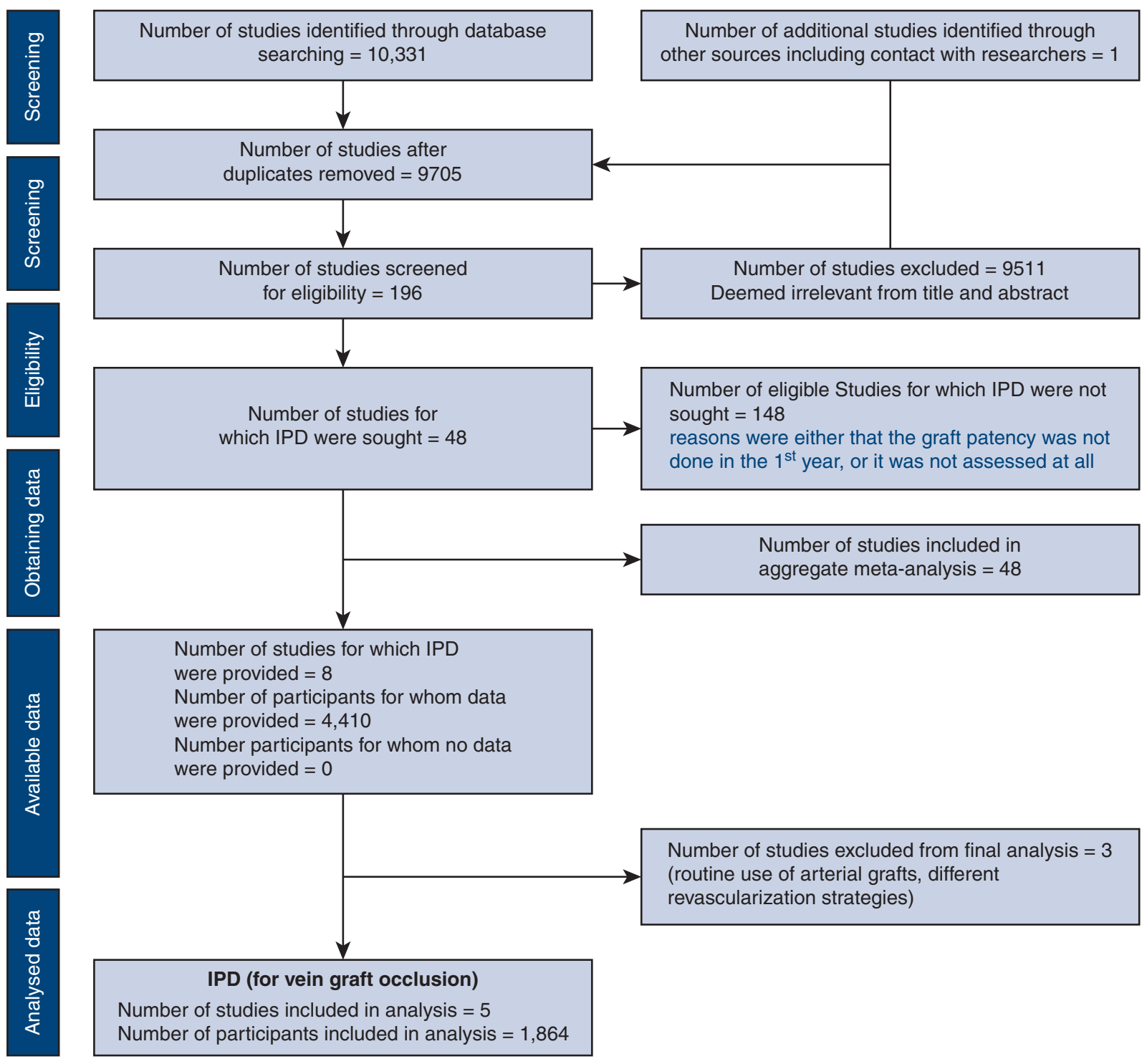

FIGURE E1. PRISMA-IPD flow chart for the study. IPD, Individual patient data. 


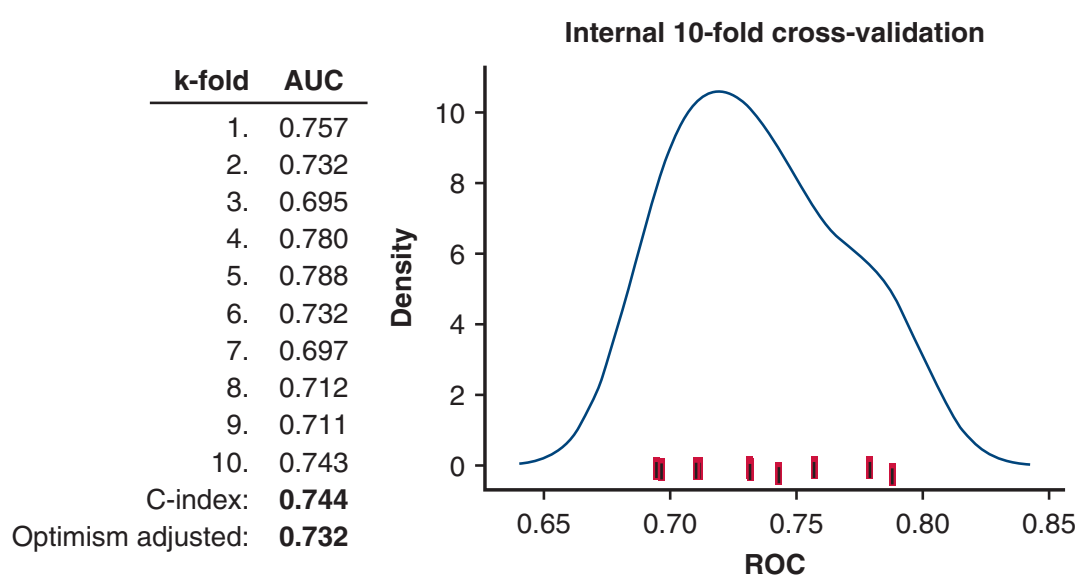

FIGURE E2. Model training with internal validation in the derivation cohort with 10-fold cross-validation and optimism adjusted c-index. AUC, Area under the curve; $R O C$, receiver operating characteristic. 
TABLE E1. Summary of identified studies on early saphenous vein graft patency post-coronary artery bypass operation

\begin{tabular}{|c|c|c|c|c|c|c|c|c|c|c|c|}
\hline \multirow[b]{2}{*}{ Study } & \multirow[b]{2}{*}{ Period } & \multirow[b]{2}{*}{ Size, $n$} & \multirow[b]{2}{*}{ Grafts, $n$} & \multirow[b]{2}{*}{$\begin{array}{l}\text { On/off } \\
\text { pump }\end{array}$} & \multirow[b]{2}{*}{ Time point } & \multirow{2}{*}{\multicolumn{2}{|c|}{ Completeness }} & \multicolumn{4}{|c|}{ Occlusion $(\%)$} \\
\hline & & & & & & & & 0-1 m & $3 \mathrm{~m}$ & $6 \mathrm{~m}$ & $12 \mathrm{~m}$ \\
\hline${\text { Sabik et } \text { al }^{47}}^{47}$ & 1972-1999 & 4333 & 8733 & On/off & $1 \mathrm{y}$ & ICA & 9 & - & - & - & 22.0 \\
\hline Mehta et $\mathrm{al}^{39}$ & $2002-2003$ & 3,014 & 6,280 & On/off & $<1 \mathrm{y}$ & ICA & 79 & - & - & - & 22.1 \\
\hline Nakano et $\mathrm{al}^{40}$ & $2000-2005$ & 1422 & 964 & Off & $<1 \mathrm{mo}$ & ICA & 89 & 7.0 & - & - & - \\
\hline Fitzgibbon $\mathrm{al}^{3}$ & 1969-1994 & 1388 & 5,065 & On & $<1 \mathrm{mo}$ and $1 \mathrm{y}$ & ICA & 83 & 12.0 & - & - & 19.0 \\
\hline Hattler et $\mathrm{al}^{31}$ & 2002-2007 & 1370 & 2,603 & On/off & $<1 \mathrm{y}$ & ICA & 62 & - & - & - & 19.7 \\
\hline Ohira et $\mathrm{a}^{43}$ & $<2017$ & 1176 & 660 & On/off & $1 \mathrm{wk}$ & CTA & 35 & 6.0 & - & - & - \\
\hline Raza et $\mathrm{al}^{4}$ & $1972-2011$ & 985 & 1450 & On/off & $1 \mathrm{y}$ & ICA & 21 & - & - & - & 14.0 \\
\hline Fukui et $\mathrm{al}^{23}$ & 2004-2009 & 930 & 497 & Off & $<1 \mathrm{mo}$ and $1 \mathrm{y}$ & ICA & 48 & - & - & - & 17.4 \\
\hline Tan et $\mathrm{al}^{7}$ & 1987-1990 & 912 & 1607 & On & $1 \mathrm{y}$ & ICA & 96 & - & - & - & 12.9 \\
\hline Sanz et $\mathrm{al}^{48}$ & 1984-1988 & $741 *$ & 1487 & On & $<1 \mathrm{mo}$ & ICA & 83 & 13.5 & - & - & - \\
\hline Wu et $\mathrm{al}^{53}$ & 2009-2012 & 582 & 1296 & On & $<1 \mathrm{mo}$ & ICA & 90 & 2.4 & - & - & - \\
\hline Desai et $\mathrm{al}^{22}$ & 1996-2001 & 440 & 440 & On & $12 \mathrm{mo}$ & ICA & 78 & - & - & - & 13.6 \\
\hline Goldman $^{27}{ }^{27}$ & 1983-1986 & $406^{*}$ & 1,315 & On & $1 \mathrm{wk}$ and $1 \mathrm{y}$ & ICA & 81 & - & - & - & 17.7 \\
\hline Kim YH et $\mathrm{al}^{34}$ & 2011-2014 & 368 & 812 & Off & $1 \mathrm{wk}$ and $1 \mathrm{y}$ & ICA & 60 & 2.0 & - & - & 6.2 \\
\hline Goldman et $\mathrm{al}^{29}$ & 2003-2009 & 367 & 269 & On/off & $1 \mathrm{wk}$ and $12 \mathrm{mo}$ & ICA & 97 & 3.0 & - & - & 11.0 \\
\hline McLean et $\mathrm{al}^{6}$ & 2003-2006 & 291 & 611 & On/off & $<6 \mathrm{mo}$ & CTA & 81 & - & - & 20.1 & - \\
\hline Widimsky et $\mathrm{al}^{5}$ & $<2004$ & 255 & 384 & On/off & $1 \mathrm{y}$ & ICA & 64 & - & - & - & 46.2 \\
\hline Kim $\mathrm{KB}$ et $\mathrm{al}^{33}$ & $1998-2001$ & 240 & 121 & Off & $<1 \mathrm{mo}$ and $1 \mathrm{y}$ & ICA & 60 & 2.4 & - & - & 7.1 \\
\hline Gao $C$ et $\mathrm{al}^{24}$ & 2002-2006 & 237 & 641 & On/off & $1 \mathrm{mo}$ and $1 \mathrm{y}$ & CTA & 100 & 1.1 & - & - & 4.4 \\
\hline Gao $\mathrm{G}$ et $\mathrm{al}^{25}$ & $2007-2008$ & 224 & 470 & On/off & $3 \mathrm{mo}$ & CTA & 90 & - & 17.2 & - & - \\
\hline Tanaka et al $^{52}$ & 2009-2012 & 199 & 253 & On/off & $<6 \mathrm{mo}$ & ICA & 64 & - & - & 10.3 & - \\
\hline Puskas et al ${ }^{46}$ & $2000-2001$ & 197 & 372 & On/off & $1 \mathrm{mo}$ and $1 \mathrm{y}$ & ICA & 93 & 2.3 & - & - & 5.8 \\
\hline Oshima et $\mathrm{al}^{44}$ & 2009-2015 & 196 & 112 & On/off & $1 \mathrm{mo}$ & ICA & 40 & 7.1 & - & - & - \\
\hline Goldman et $\mathrm{al}^{28}$ & 1977-1981 & $176^{*}$ & 333 & On & $1 \mathrm{wk}$ & ICA & 72 & 7.4 & - & - & - \\
\hline Chesebro et $\mathrm{al}^{20}$ & 1986-1988 & $176^{*}$ & 231 & On & $<6 \mathrm{mo}$ & ICA & 88 & - & - & 3.0 & - \\
\hline Campeau et al ${ }^{19}$ & 1969-1972 & 172 & 306 & On & $2 \mathrm{wk}$ and $1 \mathrm{y}$ & ICA & 70 & 11.0 & - & - & 23.8 \\
\hline Kobayashi et al $^{35}$ & 2002-2004 & 167 & 40 & On/off & $<1 \mathrm{mo}$ & ICA & 100 & 2.5 & - & - & - \\
\hline Noiseaux et $\mathrm{al}^{42}$ & $<2017$ & 157 & 512 & On/off & $1 \mathrm{y}$ & CTA & 98 & - & - & - & 3.7 \\
\hline Al-Ruzzeh et a ${ }^{14}$ & $<2006$ & 151 & 128 & On/off & $3 \mathrm{mo}$ & ICA & 90 & - & 14.8 & - & - \\
\hline Sousa Uva et al ${ }^{50}$ & $<2010$ & 147 & 181 & On/off & $1 \mathrm{mo}$ & CTA & 94 & 10.5 & - & - & - \\
\hline Mannacio et al ${ }^{38}$ & 2006-2009 & 144 & 267 & Off & $12 \mathrm{mo}$ & CTA & 96 & - & - & - & 10.2 \\
\hline Yun et $\mathrm{al}^{56}$ & $2000-2002$ & 144 & 336 & On & $6 \mathrm{~m}$ & ICA & 72 & - & - & 19.4 & - \\
\hline Campbell et al ${ }^{18}$ & $<2009$ & 130 & 294 & On & $<1 \mathrm{y}$ & CTA & 100 & - & - & - & 12.5 \\
\hline Gavaghan et $\mathrm{a}^{26}$ & 1984-1987 & $127 *$ & 362 & On & $1 \mathrm{wk}$ and $1 \mathrm{y}$ & ICA & 92 & 1.6 & - & - & 5.8 \\
\hline Yamane et $\mathrm{al}^{54}$ & 2007-2014 & 123 & 123 & On/off & $1 \mathrm{wk}$ & CTA & 62 & 4.5 & - & - & 14.8 \\
\hline Lingaas et $\mathrm{al}^{37}$ & $<2006$ & 120 & 193 & On/off & 0.3 and $12 \mathrm{mo}$ & ICA & 93 & 3.0 & 12.5 & - & 16.5 \\
\hline Kulik et $\mathrm{al}^{36}$ & 2006-2009 & 113 & $\mathrm{n} / \mathrm{a}$ & On/off & $1 \mathrm{y}$ & ICA & 81 & - & - & - & 4.5 \\
\hline Cho et $\mathrm{al}^{21}$ & 1995-1997 & 109 & 227 & On & $1 \mathrm{y}$ & ICA & 55 & - & - & - & 17.6 \\
\hline Bassri et a ${ }^{16}$ & $2007-2008$ & 107 & 250 & On/off & $<1 \mathrm{mo}$ & CTA & 100 & 6.6 & - & - & - \\
\hline Khan et al ${ }^{32}$ & $2000-2002$ & 104 & 260 & On/off & $3 \mathrm{mo}$ & ICA & 99 & - & 4.0 & - & - \\
\hline Brown et $\mathrm{al}^{17}$ & 1976-1980 & $83^{*}$ & 252 & On & $1 \mathrm{y}$ & ICA & 86 & - & - & - & 13 \\
\hline Sun et $\mathrm{al}^{51}$ & 2006-2008 & 79 & 181 & On/off & $1 \mathrm{mo}$ & CTA & 80 & 6.7 & - & - & - \\
\hline Arampatzis et $\mathrm{al}^{15}$ & $<2016$ & 75 & 126 & On/off & $1 \mathrm{wk}$ & CTA & 50 & 4.7 & - & - & - \\
\hline
\end{tabular}




\begin{tabular}{|c|c|c|c|c|c|c|c|c|c|c|c|}
\hline \multirow[b]{2}{*}{ Study } & \multirow[b]{2}{*}{ Period } & \multirow[b]{2}{*}{ Size, $n$} & \multirow[b]{2}{*}{ Grafts, n } & \multirow[b]{2}{*}{$\begin{array}{l}\text { On/off } \\
\text { pump }\end{array}$} & \multirow[b]{2}{*}{ Time point } & \multirow{2}{*}{\multicolumn{2}{|c|}{$\begin{array}{cc} & \text { Completeness } \\
\text { Modality } & \text { FU, } \%\end{array}$}} & \multicolumn{4}{|c|}{ Occlusion $(\%)$} \\
\hline & & & & & & & & $0-1 \mathrm{~m}$ & $3 \mathbf{m}$ & $6 \mathrm{~m}$ & $12 \mathrm{~m}$ \\
\hline Nathoe et $\mathrm{al}^{41}$ & $1998-2000$ & 70 & 158 & On/off & $1 \mathrm{y}$ & ICA & 64 & - & - & - & 8.0 \\
\hline 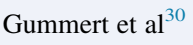 & $<2006$ & 54 & 51 & On/off & $6 \mathrm{mo}$ & CTA/ICA & 94 & - & - & 1.9 & - \\
\hline Yoo et $\mathrm{al}^{55}$ & $<2002$ & 42 & 55 & On/off & $<3 \mathrm{mo}$ & CTA/ICA & 100 & - & 3.6 & - & - \\
\hline Perrault et al ${ }^{45}$ & 2004 & 35 & 59 & On/off & $3 \mathrm{mo}$ & ICA & 80 & - & 15.2 & - & - \\
\hline Song et $\mathrm{al}^{49}$ & 2008-2009 & 25 & 50 & Off & $1 \mathrm{wk}$ and $1 \mathrm{y}$ & CTA & 100 & 0.0 & - & - & 5.3 \\
\hline Total & & 23,103 & 41,530 & Number of SVGs assessed & & 13,944 & 1165 & 1482 & 33,446 & & \\
\hline
\end{tabular}

FU, Follow-up; on, on-pump coronary artery bypass; off, off-pump coronary artery bypass; ICA, invasive coronary angiography; $C T A$, computed tomography angiography; $n / a$, not available. *Placebo group not included in summary statistics (study numbers correspond to the reference list of the main manuscript).

TABLE E2. Demographic characteristics of clinical cohorts included in the IPD analysis

\begin{tabular}{|c|c|c|c|c|c|c|}
\hline & $\begin{array}{l}\text { Oxford, United } \\
\text { Kingdom }\end{array}$ & $\begin{array}{c}\text { Baltimore, } \\
\text { Md }\end{array}$ & $\begin{array}{c}\text { Montreal, } \\
\text { Canada }\end{array}$ & $\begin{array}{c}\text { Naples, } \\
\text { Italy }\end{array}$ & $\begin{array}{l}\text { Toronto, } \\
\text { Canada }\end{array}$ & Total \\
\hline Study population, $\mathrm{n}$ & 226 & 295 & 35 & 868 & 440 & 1864 \\
\hline \multicolumn{7}{|l|}{ Clinical demographics } \\
\hline Age, y & $65.5(9.3)$ & $63.4(10.0)$ & $66.2(9.3)$ & $59.7(8.2)$ & $60.8(8.4)$ & $61.3(9.0)$ \\
\hline Males, \% & 86.7 & 79.1 & 97.2 & 73.0 & 87.0 & 79.5 \\
\hline BMI, $\mathrm{kg} / \mathrm{m}^{2}$ & $28.1 \pm 4.3$ & $29.8 \pm 6.2$ & $28.2 \pm 3.6$ & $26.5 \pm 3.2$ & - & $27.3(4.2)$ \\
\hline Hypertension, \% & 74.3 & 82.1 & 86.1 & 60.6 & 46.1 & 62.7 \\
\hline Dyslipidemia, $\%$ & 89.8 & 83.7 & 94.4 & 57.7 & 68.5 & 68.9 \\
\hline Diabetes, $\%$ & 23.9 & 34.8 & 27.8 & 15.9 & 26.1 & 22.5 \\
\hline Previous MI, \% & 47.8 & 40.5 & - & - & 46.1 & 48.7 \\
\hline \multicolumn{7}{|l|}{ NYHA class, \% } \\
\hline $\mathrm{I} / \mathrm{II}$ & $44.9 / 43.1$ & $88.5 / 3.4$ & $32.8 / 50.0$ & $38.4 / 47.1$ & & $48.0 / 37.8$ \\
\hline III/IV & $10.2 / 1.8$ & $5.4 / 2.7$ & $11.8 / 5.9$ & $11.1 / 3.5$ & - & $10.7 / 3.5$ \\
\hline LVEF $<50 \%, \%$ & 14.3 & 0.3 & 20.6 & 35.7 & 51.4 & 31.0 \\
\hline Creatinine, $\mathrm{mg} / \mathrm{dL}$ & $0.93(0.21)$ & $1.00(0.24)$ & - & $1.05(0.43)$ & $1.05(0.210)$ & $1.03(0.34)$ \\
\hline \multicolumn{7}{|l|}{ Number of VD, $\%$} \\
\hline 1 & 4.9 & 1.4 & 0.0 & 0.0 & & 1.1 \\
\hline 2 & 22.1 & 14.9 & 14.3 & 22.9 & & 19.0 \\
\hline 3 & 73.0 & 83.7 & 85.7 & 77.1 & & 79.9 \\
\hline \multicolumn{7}{|c|}{ Operative characteristics, $\%$} \\
\hline Urgent & 0.0 & 37.6 & 0.0 & - & 33.0 & 23.9 \\
\hline On-pump & 18.6 & 97.6 & 88.9 & 5.9 & 100 & 45.8 \\
\hline $\mathrm{EVH}$ & 86.3 & 53.4 & - & 0.0 & 0.0 & 21.0 \\
\hline \multicolumn{7}{|l|}{ SVG number, $\%$} \\
\hline 1 & 37.2 & 26.4 & 80.0 & 43.4 & 100.0 & 54.0 \\
\hline 2 & 48.2 & 42.4 & 20.0 & 52.2 & 0.0 & 37.2 \\
\hline$\geq 3$ & 14.6 & 31.2 & 0.0 & 4.4 & 0.0 & 8.8 \\
\hline \multicolumn{7}{|l|}{ Target vessel, $\%$} \\
\hline Diagonal & 40.3 & 50.9 & 17.1 & 15.0 & - & 27.8 \\
\hline $\mathrm{LCx} / \mathrm{OM}$ & 61.1 & 69.2 & 22.9 & 52.9 & - & 52.6 \\
\hline RCA & 69.9 & 66.1 & 60.0 & 94.6 & - & $74 / 8$ \\
\hline Complex grafts, $\%$ & 3.2 & - & 2.9 & 2.9 & - & 9.3 \\
\hline Follow-up time, mo & $<12$ & 6 & 3 & 12 & 12 & $<12$ \\
\hline Occlusion, \% & 11.5 & 33.4 & 8.5 & 7.6 & 13.6 & 13.7 \\
\hline
\end{tabular}

$B M I$, Body mass index; $M I$, myocardial infarction; $N Y H A$, New York Heart Association; $L V E F$, left ventricular ejection fraction; $V D$, vessel disease; $E V H$, endoscopic vein harvesting; $S V G$, saphenous vein graft; $L C x$, left circumflex; $O M$, obtuse marginal; $R C A$, right coronary artery. 